\title{
Clinical impact of molecular diagnosis in cat allergy
}

\author{
Silvia Uriarte Obando*, Joaquín Sastre Domínguez \\ From 5th International Symposium on Molecular Allergology (ISMA 2013) \\ Vienna, Austria. 6-7 December 2013
}

\section{Background}

Allergy to cat is a frequent cause of rhinitis, asthma or contact urticaria. Dander, saliva and urine are sources of cat allergens. The prevalence of sensitization to different cat allergens is not well known.

\section{Methods}

We select 105 sensitized patients to cat. Specific IgE measurement to cat allergens Fel d1, Fel d2 and Fel d4 was performed by ImmunoCAP ${ }^{\circledR}$ and/or microarray ISAC ${ }^{\circledR}$ (ThermoFisher Scientific, Sweden), a value $>0,35 \mathrm{kU} / \mathrm{L}$ or $>0,3$ ISU was considered as positive, respectively. Skin prick test was performed with an ALK-Abelló extract (Denmark). Association of Specific IgE measurements and presence and type of rhinitis or asthma was studied. Statistical analysis was performed using Fisher test and chi-squared test.

\section{Results}

$88 \%$ of patients had specific IgE to Fel d1, $22 \%$ to Fel d2, and $42 \%$ to Fel d $4.48 \%$ were monosensitized to Fel d1, $7 \%$ to Fel d2 and $4 \%$ to Fel d $4.86 \%$ of sensitized patients to Fel d4 were also sensitized to Fel d1. Fel d2 was associated with severity of rhinitis and asthma ( $p<0.01$, p 0.01, respectively). Fel d4 was associated with presence of asthma symptoms $(\mathrm{p}<0.04)$. Direct contact with cats was associated both to persistence and severity of rhinitis (p 0.0003, p 0.0001, respectively). A positive skin prick test to cat was associated with rhinitis and asthma symptoms ( $\mathrm{p}<0.01, \mathrm{p}<0.01$, respectively).

\section{Conclusion}

Different patterns of sensitization to cat allergens in patients with cat allergy can help us to predict the severity and persistence of symptoms.

\section{Published: 17 March 2014}

Fundación Jiménez Díaz, Allergy Department, Madrid, Spain

@ 2014 Uriarte Obando and Sastre Domínguez; licensee BioMed Central Ltd. This is an Open Access article distributed under the terms of the Creative Commons Attribution License (http://creativecommons.org/licenses/by/2.0), which permits unrestricted use,

C Biomed Central distribution, and reproduction in any medium, provided the original work is properly cited. The Creative Commons Public Domain Dedication waiver (http://creativecommons.org/publicdomain/zero/1.0/) applies to the data made available in this article, unless otherwise stated.
doi:10.1186/2045-7022-4-S2-P51

Cite this article as: Uriarte Obando and Sastre Domínguez: Clinical impact of molecular diagnosis in cat allergy. Clinical and Translational Allergy 20144 (Suppl 2):P51.
Submit your next manuscript to BioMed Central and take full advantage of:

- Convenient online submission

- Thorough peer review

- No space constraints or color figure charges

- Inclusion in PubMed, CAS, Scopus and Google Scholar

- Research which is freely available for redistribution

Submit your manuscript at Submit your manuscript at C BioMed Central
- Immediate publication on acceptance 